\title{
Efficient Use of Audio-Visual Equipment in Teaching and Learning: Its Implication to School Supervision
}

\author{
Raquel B. Coronado, Elymar A. Pascual, Josefa U. Orijola \\ elymarpascual@rocketmail.com \\ Department of Educaiton, Nagcarlan District, Nagcarlan, Laguna, Philippines, 4002
}

\begin{abstract}
This paper aimed at determining the possible effectiveness of the use of audio-visual equipment in English, Math and Science subjects to the academic performance of grade 8 learners in Talangan Integrated National High School. Three sections of grade 8 and their teachers in English, Math and Science became part of this action research. At the end of the study, implication to school supervision was lined-up to improve teaching strategy among teachers. The three sections of Grade 8 (Courteous, Caring and Charity), with a total number of 102 became part of the population for this study. This paper is a qualitative, experimental research which took note on the performance of the learners in three subjects - English, Science and Mathematics. Three quizzes were given on all subjects after each session without the use of audio-visual material. After that, audio-visual materials are used and another three quizzes were given after each session. Without the use of audio-visual material, the mean level of learners are 5.48, 6.91 and 4.27 in English, Mathematics and Science, respectively, in quizzes which are out of 10. On the other hand, the mean level of learners in a quiz with 10 items and using audio-visual material are $9.00,8.48$ and 4.45 in the said three subjects, respectively. Using ttest for paired sample mean, it was found out (with the assurance of the p-values 0.01, 0.00 and 0.22 for English, Science and Mathematics, respectively) that the use of audio-visual materials significantly improved learner's performance only in English and Science. Recommendations to teachers, school heads, district and division officials, and to future researchers were given at the end of the study. Implications to school supervision, especially on classroom observation, are also mentioned to guide school heads and master teachers in improving teaching strategy among teachers.
\end{abstract}

Keywords: audio-visual; equipment; English; Mathematics; Science; learners; performance

\section{Introduction}

Since the outset of computer technology in the early 1970's, various fields of work and study have embraced the necessity of it, and other related equipment that suggest the proliferation of knowledge in the modern times. Audio-visual equipment has not just become part of daily living, leisure and past-time, but a means of making task easy and enjoyable. The old-style Betamax and VHS players were replaced by VCD and DVD players, desktops, laptops and mobile phones.

Students today are acquainted with modern-day gadgets. Add to these are the free applications available in the internet that make them connected to the world. These way of acquiring knowledge and information have been brought even to the classroom setting as seen by many as part of $21^{\text {st }}$ Century learners' environment. From kindergarten to elementary, audio-visual equipment has been a necessary tool in bringing the lesson to kids and young alike. Teachers are challenged to be updated with the use of technology so as not to make a mismatch with teaching and learning.

Various studies have been conducted in different subject areas with regards to the use of audio-visual equipment - Math, English, Science, Music, Health, Social Science, and other subject areas. Has it been established that the use of audio-visual equipment significantly help in learning these subject areas? The focus 
of this paper is on this issue.

\subsection{Background of the Study}

Talangan Integrated National High School updates itself in the use of technology. Fund from Maintenance and Other Operating Expenses (MOOE) has the availing of audio-visual equipment part of its trust - multimedia projector, LED monitor, DVD players, desktops, etc. With its growing population, add to it is the Senior High School learners, the delivery of knowledge should not lag behind target with the aid of these equipment. During the evaluation of Mean Percentage Score of Second Quarter Exam, the grade 8 learners got a low point. Grade 8 is composed of three sections with around 35 learners each. They are the Grade 8 Courteous, Grade 8 Caring and Grade 8 Charity. Because of this, a solution to increase performance became the objective of this study. Can audio-visual equipment help in this purpose?

\subsection{Theoretical Framework}

Gopal (2010) mentioned that "audio-visual materials help the teacher to overcome physical difficulties of presenting subject matter." Through audio-visual materials, important points and concepts that might be forgotten to be mentioned can be avoided when there is a ready audio-visual material. Unavailability of structure, equipment and mechanisms that can be showed through audio-visual equipment can facilitate teachers in relaying the topic to the learners.

Also, Gopal (2010) theorized that audio-visual resources make learning permanent. "Audio-visual methods do seem to facilitate the acquisition, the retention and the recall of lessons learned, because, they seem to evoke the maximum response of the whole organism to the situations in which learning is done." This is supported by the famous maxim, "What I hear, I forget. What I see, I remember. What I do, I know." The things that learners see on the screen or monitor has a great impact to their memory retention in the sense that it has added colors and capturing sound effects rather than just seeing from the teacher or other learners doing the task or skill.

\subsection{Conceptual Framework}

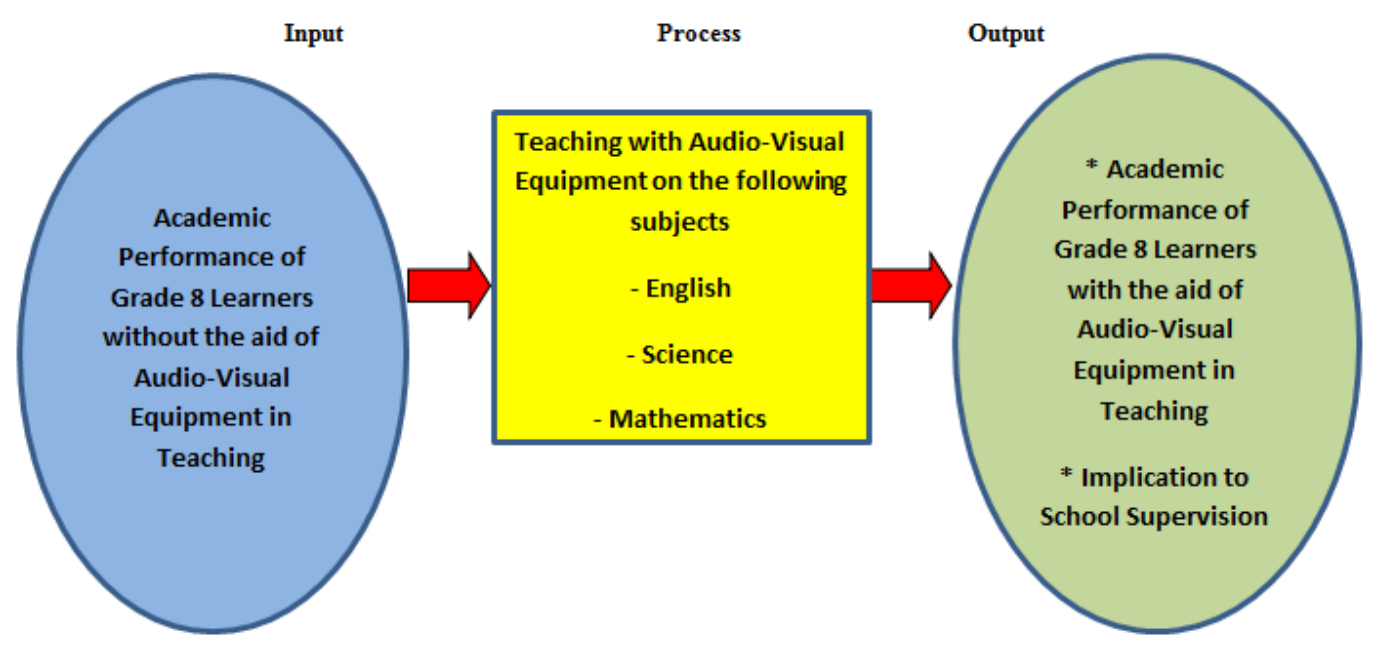

Fig. 1. The paradigm 
The figure in the previous page shows the paradigm of the study. Frame 1 at the left side is consist of the academic performance of grade 8 learners without the aid of audio-visual equipment in teaching and learning. Frame 2 in the middle is comprised of the utilization of the audio-visual equipment in English, Science and Math subjects. And frame 3 at the right side is composed of the academic performance of the grade 8 learners when teaching and learning utilize audio-visual equipment.

\subsection{Statement of the Problem}

This study will focus on determining the possible effectiveness of the use of audio-visual equipment in teaching English, Science and Mathematics to Grade 8 learners of Talangan Integrated National High School.

Specifically, it seeks to answer the following question.

- What is the mean level of academic performance of grade 8 learners without the use of audio visual equipment in the following subjects:

* English;

* Science; and

* Mathematics?

- What is the mean level of academic performance of grade 8 learners with the use of audio visual equipment in the following subjects:

* English;

* Science; and

* Mathematics?

- Is there a significant difference in the academic performance of grade 8 learners with and without the use audio visual equipment in teaching? And

- What is the implication of the use of audio-visual equipment in the area of school administration and supervision?

\subsection{Scope and Limitations}

Talangan Integrated National High School offers junior and senior high school curriculum. This study focuses on the effectivity of audio-visual equipment on the academic performance of Grade 8 learners only. Out of eight subjects, this study focused on three main subjects only, name, English, Science and Mathematics.

\section{Review of Related Literature}

Sobejana (2016) had a study on the use of e-learning strategies and its relationship on academic performance of 252 college students in Basic English of UM Digos College (UMDC), Cor Jesu College (CJC), Polytechnic College of Davao del Sur (PCDS), South Philippines Adventist College (SPAC), Southern Philippines Agri-Business and Marine and Aquatic School of Technology (SPAMAST), and Holy Cross of Bansalan College (HCBC). The study revealed that among the five indicators of e-learning (provision of learning activities, learner-faculty interaction, learner-software interaction, learner-hardware interaction and collaboration among learners), only learner-faculty interaction was found to be significantly correlated with academic performance.

Haahr (2005), in explaining student performance as evidenced from the international PISA, TIMSS and PIRLS surveys, said that a range of assessment methods can be used in order to assess students' academic progress: Standardized tests, the assessment of student portfolios, judgmental ratings carried out by teachers, regular teacher-developed tests and assessments of student assignments, projects, and homework. 
In a synthesis relating to achievement, Hattie (2009) said, "It is students themselves, in the end, not teachers, who decide what students will learn. Thus we must attend to what students are thinking, what their goals are, and why they would want to engage in learning what is offered in schools."

Anand (2009) conducted a study on students' performance in two semesters of Cell Biology course. Teaching strategies, behaviors, and pre-course variables were analyzed with respect to students' performance... Chi-square tests of independence showed that completion of chemistry requirements, passing the laboratory component of Cell Biology, homework, and attendance were related to passing our course. Logistic regression showed that perfect attendance followed by GPA, were the most important factors associated with passing the course.

In a study made by Katsikas (2010), the academic and social profiles of 867 students, studying in a university of Economic and Social Studies, are analysed by means of Ordinary Least Squares and Quantile Regression Methods. Study showed that working students do not achieve lower grades than non-working peers.

Yusuf (2017) focused on the subject social studies. The researcher's study revealed that there is a significant effect of a teaching method on academic performance of students in social studies. Second, there is a significant influence of family background on academic performance in social studies. Also, there is a significant effect of learning strategies on learning outcomes of students in social studies.

Martha (2009) made a connected study on this. It was designed to investigate the factors affecting academic performance of undergraduate students of Uganda Christian University (UCU). The findings revealed the existence of a significant relationship between students' A-level and Diploma admission points and academic performance, but there was no relationship between mature age points and academic performance. The findings also revealed that there was a significant relationship between parents' social economic status and academic performance and a significant relationship between former school background and academic performance.

Falsario's (2014) study focused on the relationship between classroom climate and student's academic performance. The respondents were the 123 fourth year Bachelor of Secondary Education and Bachelor of Elementary Education students taking the Teaching Profession. Study revealed that classroom climate to a certain extent has some influence on academic performance of students.

Wenglinsky (2001) found out in his study that the effects of classroom practices, when added to those of other teacher characteristics, are comparable in size to those of student background, suggesting that teachers can contribute as much to student learning as the students themselves.

All the above-mentioned readings are related to the present study because they bring about what has been studied in academic performance and its relation to different factors.

On the aspect of audio-visual equipment, Narayan (1980) made a training document aids. The purpose of this paper is to draw the attention of pre-school and primary school teachers to the importance and scope of audio-visual aids in the educational programmes and activities designed for pre-school and primary school children in developing countries. According to the writer, audio-visual aids which have a decisive influence on the quality of learning in pre-school institutions and primary schools are essential and should be made available if the children are to be stimulated in their own learning. Use of audio-visual aids of all types can provide exciting learning experiences to children to improve their reading, listening and observing abilities.

Al Mamun (2014) made a qualitative study on the power of audio-visual equipment. According to the concern of the teachers and the students, the use of the audio-visual aids provides the learners opportunity to have background knowledge of any topic which is necessary for the learners. The results also indicate that music can be useful additional audio-visual materials for teaching language. The data shows that one of the very useful visual aids for the language teachers is PowerPoint presentation. The result of the study also indicates that the audio-visual materials motivates the learners and helps them to lower their anxiety levels. Also, it has been found that teachers can design different language activities based on the audio-visual 
materials. All the findings from the data collection support that audio-visual aids facilitate language learning. Both the teachers and learners are benefited from different audio-visuals materials in language classrooms. Audio-visuals make the language teaching and learning effective making the class interactive and interesting, motivating the learners, facilitating language skills and so many.

"A realistic view of child learning makes it clear that now more than ever a variety of teaching aids must be employed if the education of children is to be effective," said Tyler (1943). On the other hand, Ashaver (2013) declared, "Non-availability, lack of supporting infrastructures and human factors are hindrances to the use of audio-visual aids in the college. There are numerous benefits that students derive from the use of audio-visual aids."

Al-Khalifah (1994) had a related study on the use of audio-visual equipment. It explores the benefit and use of audio-visual materials by teachers and lecturers in Kuwait. The study concludes that the use of audio-visual materials in teaching benefits both teachers and learners by making concepts easily understandable, overcoming physical difficulties, and stimulating enjoyment, confidence, concentration and teacher/learner communication.

All the above-mentioned readings on audio-visual equipment give light to the importance of using this strategy to aid learners in having a full grasp of their lessons, especially when used properly.

On the aspect of school supervision, Onasanya (2017) said, "Educational activities need supervision and inspection to achieve educational objective. Supervision and inspection are good machineries to up-grade teachers into required standard. Teachers need supervision and inspection to work harder no matter their level of experience an devotion. Without supervision both teachers and school administrators backslide rapidly in their performance."

Behlol (2011) made a study on supervision and supervisory practices. It was conducted to find out the practices and problems of supervisors working at primary school level in Pakistan. It revealed that supervisors do not delegate the responsibilities to the staff to perform the educational making process. As a result, the team members will not put their all-out efforts in the activity and take it as burden. It is recommended that a training programme for the supervisors working at Primary level may be designed and launched to improve their knowledge, skills and attitude to perform their duties as a facilitator, guide, motivator, helper and the leader of the team.

Forsyth (2017) in his book stated that "effective supervision in public schools is an elusive but fascinating activity, and much confusion and misapprehension surround the word "supervision" itself... Close supervision was a classic response to production and control problems: it was management's attempt to manipulate and control subordinates. It should not be surprising, then, that a good many teachers view supervisions as simply another layer in the bureaucratic structure designed to watch and control their actions."

Treslan (2017) examined the learning organization dimension of schools His purpose is to identify implications for specific components of supervision, namely, knowledge, interpersonal/technical skills and task areas. The supervisory process is argued to be significantly affected by a learning organization presence, creating additional leadership role responsibilities.

\section{Research Design and Methodology}

\subsection{Population}

Presented below is the number of learners who have completed six quizzes in three subjects (three quizzes in teaching and learning without the aid of audio-visual equipment and three quizzes in teaching and learning with the aid of audio-visual equipment). 
Table 1. Frequency of grade 8 learners who have accomplished six quizzes in three subjects

\begin{tabular}{|c|c|c|c|}
\hline Section & \multicolumn{3}{|c|}{ Number of Learners } \\
\hline & English & Math & Science \\
\hline Grade 8 Courteous & 33 & 31 & 32 \\
\hline Grade 8 Caring & 33 & 32 & 32 \\
\hline Grade 8 Charity & 34 & 29 & 38 \\
\hline Total & 100 & 92 & 102 \\
\hline
\end{tabular}

\subsection{Data Collection Procedure}

The flowchart below shows the process that the researchers underwent in accomplishing this study.

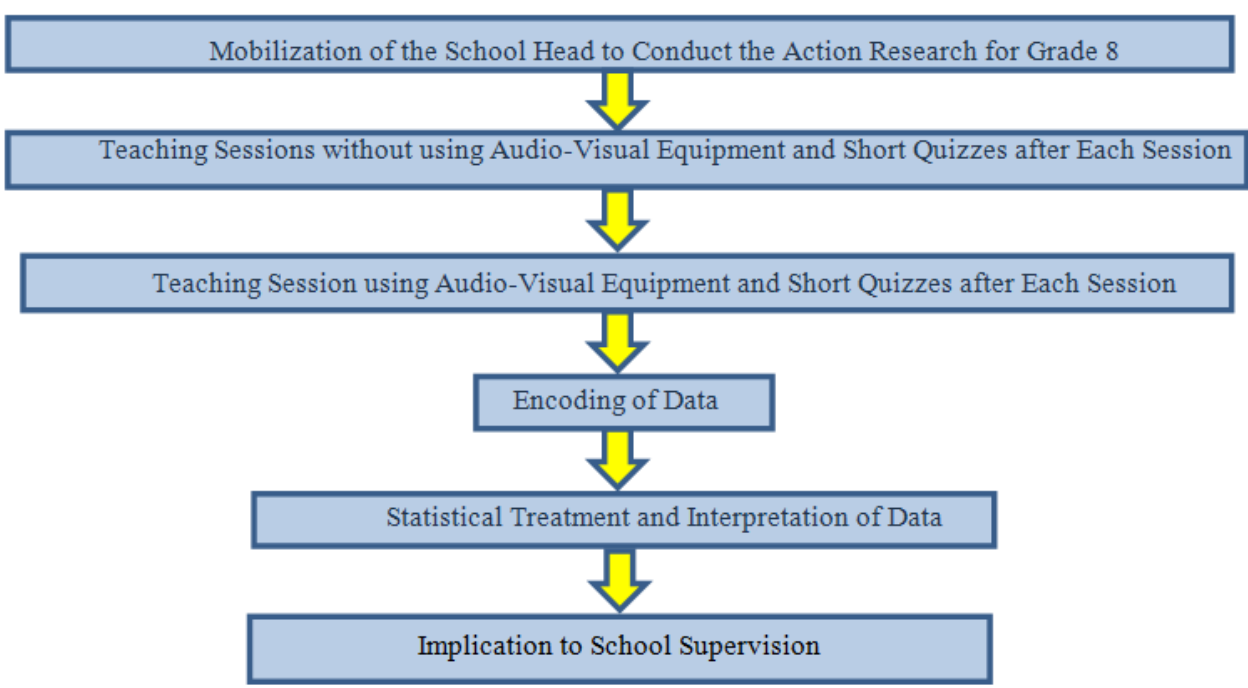

Fig. 2. Flowchart of data gathering procedure

\section{Presentation, Interpretation and Analysis of Data}

Table 2. Significant effect of the use of audio-visual equipment in English

\begin{tabular}{|c|c|c|c|c|c|c|}
\hline $\begin{array}{l}\text { Teaching } \\
\text { Strategy }\end{array}$ & Mean & SD & t-value & t-tab & p-value & Decision \\
\hline $\begin{array}{lr}\text { w/out audio- } \\
\text { visual equipment }\end{array}$ & 5.48 & 2.59 & \multirow{2}{*}{-2.59} & \multirow{2}{*}{1.98} & \multirow{2}{*}{0.01} & \multirow{2}{*}{ Significant } \\
\hline $\begin{array}{l}\text { with audio-visual } \\
\text { equipment }\end{array}$ & 9.00 & 13.54 & & & & \\
\hline
\end{tabular}

alpha $=0.05$

The table above shows the comparison of the academic performance of grade 8 learners in English after having six quizzes - three in teaching and learning without audio-visual equipment and three in teaching and learning with audio-visual equipment. Using t-test for paired sample means, it can be seen that the mean increased from 5.48 to 9.00 in a 10 -item quiz. The absolute value of $t$ value (2.59) is greater than the tabular value (1.98), showing that there is a significant difference between the two means. The average increased 
significantly. The p-value 0.01 which is lower than the alpha level $(0.05)$ strengthens the claim. The use of audio-visual material can significantly increase the academic performance in English.

The result of this study is the same as the result of the study of Al-Khalifah (1994). The researcher concluded in a study that the use of audio-visual materials in teaching benefits both teachers and learners by making concepts easily understandable, overcoming physical difficulties, and stimulating enjoyment, confidence, concentration and teacher/learner communication. Learners can enhance their learning through the use of audio-visual equipment, accompanied by teachers' explanation and examples.

Table 3. Significance effect of the use of audio-visual equipment in Science

\begin{tabular}{|c|c|c|c|c|c|c|}
\hline $\begin{array}{l}\text { Teaching } \\
\text { Strategy }\end{array}$ & Mean & SD & t-value & t-tab & p-value & Decision \\
\hline $\begin{array}{lr}\text { w/out } & \text { audio- } \\
\text { visual equipment }\end{array}$ & 6.91 & 1.93 & \multirow{2}{*}{-5.55} & \multirow{2}{*}{1.98} & \multirow{2}{*}{0.00} & \multirow{2}{*}{ Significant } \\
\hline $\begin{array}{l}\text { with audio-visual } \\
\text { equipment }\end{array}$ & 8.48 & 2.46 & & & & \\
\hline
\end{tabular}

alpha $=0.05$

Table 3 shows the comparison of the academic performance of grade 8 learners in Science after having six quizzes - three in teaching and learning without audio-visual equipment and three in teaching and learning with audio-visual equipment. Using t-test for paired sample means, it can be seen that the mean increased from 6.91 to 8.48 in a 10 -item quiz. The absolute value of $t$ value (5.55) is greater than the tabular value (1.98), showing that there is a significant difference between the two means. The average increased significantly. The p-value 0.00 which is lower than the alpha level (0.05) strengthens the claim. The use of audio-visual material can significantly increase the academic performance in Science.

The result of this study is the same as the result of the study of Al Mamun (2014). According to the concern of the teachers and the students, the use of the audio-visual aids provides the learners opportunity to have background knowledge of any topic which is necessary for the learners. Learners become interested in Science when they see phenomenon explained in audio-visual form, and not only from books or explanations from teachers.'

Table 4. Significance effect of the use of audio-visual equipment in Mathematics

\begin{tabular}{|c|c|c|c|c|c|c|}
\hline $\begin{array}{l}\text { Teaching } \\
\text { Strategy }\end{array}$ & Mean & SD & t-value & t-tab & p-value & Decision \\
\hline $\begin{array}{lr}\text { w/out audio- } \\
\text { visual equipment }\end{array}$ & 4.27 & 0.74 & \multirow{2}{*}{-1.24} & \multirow{2}{*}{1.98} & \multirow{2}{*}{0.22} & \multirow{2}{*}{ Not Significan } \\
\hline $\begin{array}{l}\text { with audio-visual } \\
\text { equipment }\end{array}$ & 4.45 & 1.27 & & & & \\
\hline
\end{tabular}

alpha $=0.05$

Table 4 shows the comparison of the academic performance of grade 8 learners in Mathematics after having six quizzes - three in teaching and learning without audio-visual equipment and three in teaching and learning with audio-visual equipment. Using t-test for paired sample means, it can be seen that the mean increased from 4.27 to 4.45 in a 10 -item quiz. The absolute value of t value (1.24) is lower than the tabular value (1.98), showing that there is no significant difference between the two means. The average does not increase significantly. The p-value 0.22 which is greater than the alpha level $(0.05)$ strengthens the claim. The use of audio-visual material cannot significantly increase the academic performance in Mathematics. Learners look more at the teachers explanation which can be paused when there is a question, rather than videos that proceeds continuously and cannot be stopped, or learners cannot ask questions that gives them difficulty to understand topics in Mathematics. 


\section{Implication to School Supervision and Recommendation}

\subsection{Implication to School Supervision}

The result seen in this study has implication to school supervision and educational leadership.

- School heads and master teachers can give credit to English and Science teachers using audio-visual equipment in teaching. On the other hand, they should not discourage traditional teaching in Mathematics with paper visual aid and chalk. This does not mean discouraging the use of audiovisual equipment in Mathematics but just limiting the use of it because learners will catch more on the lesson when it is taught in a step-by-step procedure.

- Acquisition of audio-visual equipment (DVD's and VD's, players, and educational software in English and Science should not be missed in using Maintenance and Other Operating Expenses (MOOE) because availment of this directly concerns student's learning.

- Trainings and seminar in the use of audio-visual equipment should be spearheaded by principals as the use of them will increase academic performance.

\subsection{Recommendation}

Based from the conclusions that resulted in the conduct of this study, the following recommendations to target persons are line-up here:

- School heads should update themselves in available audio-visual equipment so as to properly gear the teachers in the maximum use of available equipment. Filling the library with audio-visual materials would increase learners' interest to learn, and thus, increase academic performance.

- Master teachers should look forward to seeing the use of audio-visual equipment in their classroom observations and commend teachers using them, especially English and Science teachers.

- Teachers should explore more on using audio-equipment and update themselves in the available resources on online, both for English and Science teachers. On the other hand, Math teachers should cautiously use audio-visual equipment and just use them as additional to chalk-and-board, traditional visual aids, group activity, exploratory study and investigatory projects.

- Community officials should go hand-in-hand with the school procuring audio-visual equipment for the school and the learners.

- Future researchers should explore on the possible effectiveness of audio-visual equipment to the other subject areas like music, health, social sciences, technology and livelihood.

\section{References}

Al-Khalifah, J. (1994). Teachers' use of audio-visual media for teaching and learning in Kuwait public schools, the influence of teacher training colleges and the role of the school library in media provision, a Doctoral Thesis submitted in partial fulfillment of the requirements for the award of Doctor of Philosophy of Loughborough University

Al Mamun, A. (April 2014). Effectiveness of Audio-visual Aids in Language Teaching in Tertiary Level, BRAC Institute of Languages (BIL), BRAC University, Dhaka, Submitted in partial fulfilment of the requirement for the degree of MA in TESOL

Anand, S. and Soto, J. G. (January 2009). Journal of the Scholarship of Teaching and Learning, Vol. 9, No. 1, Factors influencing academic performance of students enrolled in a lower division Cell Biology core course, pp. 64-80

Ashaver, D., Igyuve, S.M., (May - June. 2013). The Use of Audio-Visual Materials in the Teaching and Learning Processes in Colleges of Education in Benue State-Nigeria, Benue State University, Makurdi, Nigeria, IOSR Journal of Research and Method in Education (IOSR-JRME), Vol. 1, Issue 6, pp. 44-45

Behlol, M.G., (Nov. 1, 2011). Concept of Supervision and Supervisory Practices at Primary Level in Pakistan, PMAS-Arid Agriculture University, Rawalpindi, Pakistan 
Falsario, H.N., Muyong, R.F., Nuevaespaña, J.S. (March 6-8, 2014). Classroom Climate and Academic Performance of Education Students, Southern Iloilo Polytechnic College, WVCST Miagao Campus Presented at the DLSU Research Congress 2014, De La Salle University, Manila, Philippines, Mar. 6-8, 2014

Forsyth, P.B., Hoy, W.K. (December 30, 2017). Effective Supervision, Theory into Practice

Gopal, V. P. (2010). Importance of Audio-Visual in teaching methodology. Mahourastra, India

Haahr, J. H., Hansen, M. E., Jakobsen, S. T., Nielsen, T. K.. (November 2005). Explaining Student Performance Evidence from the international PISA, TIMSS and PIRLS surveys Danish Technological Institute

Hattie, J. (2009). Visible Learning: A Synthesis of Over 800 Meta-Analysis Relating to Achievement. New York: Routledge

Katsikas, E., Panagiotidis, T. (October, 2010). Status and Academic Performance: an approach of the quality determinants of university studies in Greece, Hellenic Observatory Papers on Greece and Southeast Europe, The Hellenic Observatory, the European Institute

Martha, K. (December 2009). Factors Affecting Academic Performance of Undergraduate of Students at Uganda Christian University, by Kyoshaba Martha, BBA (UCU), Dissertation submitted to Graduate School in Partial Fulfilment of the Requirements for the Award of the Degree of Master of Arts in Educational Management of Makerere University

Narayan, S. (April 1980). Audio-Visual Aids for Pre-School and Primary School Children, A Training Document Aids to Programming UNICEF Assistance to Education, by Shankar Narayan, Unesco Report in Audio-Visual Aids and Production of Teacher Training Materials, Teacher Development Center, Teacher Training Institute, Samchi, Bhutan, Unesco, Paris.

Onasanya, S.A., (December 30, 2017). The concept and practices of supervision/inspection in Kwara State Public Primary Schools, Department of Science Education, Faculty of Education, University of Ilorin, Ilorin, Nigeria.

Sobejana, N. (January 15, 2016). Univ. of Min. Intl. Mult. Res. Jour. vol. 1, no. 1, pp. 1-13, Educational technology and academic performance of students in basic English in selected higher education institutions in Davao del Sur, Noel Sobejana, University of Mindanao, Digos City, Davao del Sur, Philippines.

Treslan, D.L., (December 30, 2017). Educational Supervision in a "Transformed" School Organization, Faculty of Education Memorial University of Newfoundland.

Tyler, K. (1943). Audio-Visual Teaching Aids are Essential! By Keith Tyler, Tools for Learning, Association for Supervision and Curriculum Development

Wenglinsky, H. (September 2001). Teacher Classroom Practices and Student Performance: How Schools Can Make a Difference, Educational Testing Center, Statistics and Research Divisoin, Princeton, NJ.

Yusuf, A. (December 30, 2017). Inter-relationship among Academic Performance, Academic Achievement and Learning Outcomes. 